\title{
Analyses of bioindicators and physicochemical parameters of water of Lake Tondano, North Sulawesi Province, Indonesia
}

\author{
PRABANG SETYONO^, WIDHI HIMAWAN"^ \\ Department of Biology, Faculty of Mathematics and Natural Sciences, Universitas Sebelas Maret. Jl. Ir. Sutami 36A, Surakarta 57 126, Central Java, \\ Indonesia. Tel./fax.: +62-271-663375, "email:prabangsetyono@gmail.com; ”v widhi_himawan@rocketmail.com
}

Manuscript received: 12 May 2017. Revision accepted: 20 April 2018.

\begin{abstract}
Setyono P, Himawan W. 2018. Analyses of bioindicators and physicochemical parameters of water of Lake Tondano, North Sulawesi Province, Indonesia. Biodiversitas 19: 867-874. The water quality of Lake Tondano is affected by various anthropogenic activities on the water body and catchment area. The purposes of this research were (i) to identify a pollution load based on the study of bioindicators and physicochemical parameters and (ii) to identify the trophic level of the Lake Tondano. The research data were collected by direct water sampling and analyses of a secondary data. The plankton identification was conducted in a laboratory. The data were analyzed to determine biodiversity index (ID) using the Shannon Weiner formula. A comparison between physicochemical parameters and the standard in the government regulation number 82, the year of 2001 and the value of diversity index were used to determine the pollution level. The trophic level was calculated with the Carlson Formula. The results showed that the diversity index (H') in Lake Tondano was 1.904 (phytoplankton), 1.712 (zooplankton) and 2.086 (benthos) which indicated a low to mid-level pollution. Based on the government regulation, the Eris station had inappropriate water quality for the present utilization (Class II). The trophic state was categorized as eutrophic towards hypertrophic condition indicated by domination of the phytoplankton and large covers of the water hyacinth.
\end{abstract}

Keywords: Biodiversity, eutrophication, Lake Tondano, water pollution

\section{INTRODUCTION}

The problems of water in lake and reservoir are the impact of climate change, eutrophication, an interactive effect of anthropogenic activities (Ismest'eva 2015), population growth and land conversion (Chalar et al. 2011), urbanization and industrialization (Effendi 2016). A study by Dodson et al. (2000) on various type of lakes confirmed a strong correlation between anthropogenic interests and ecosystem attributes including the biodiversity changes.

Contamination of anthropogenic phosphorus and nitrogen was the factor of eutrophication in freshwater. Nutrient overload ( $\mathrm{P}$ and $\mathrm{N}$ ) will enhance the trophic level to point detrimental to the ecosystem structure and function (Xu and Zhang 2012). Both ( $\mathrm{P}$ and $\mathrm{N}$ ) are considered as the major contributors of eutrophication (Vollenweider 1968). Today, the eutrophication impact is detected in a lentic waterbody which has a relatively closed circulation such as a lake and a reservoir. Izmest'eva (2015) states that eutrophication and rise of temperature are global problems which give negative impacts on the water biodiversity. These problems also happen in Indonesia resulted from to use of lake water body as a part of fish farming and agricultural development in the catchment area.

The water resources problem globally related to their sustainability, availability, management, and conservation (Avans et al. 2012). Freshwater problems in Indonesia are related to the 7 criteria of lakes degradation: (i) sedimentation, (ii) pollution, eutrophication, water quality degradation, (iii) lakes utilization, (iv) a commitment between government and communities, (v) a lakes strategy for the national function, (vi) biodiversity (endemic species) and (vii) a disaster vulnerability. Lake Tondano is included in the 15 priority lakes to be managed because it is degraded (Soeprobowati et al. 2016).

Tondano is the main lake on North Sulawesi, Indonesia covering $44-48 \mathrm{~km}^{2}$ of water area. The lake was an estuary of the 3 main rivers (Panasen, Noongan, and Wuliling) which has only a single outlet to the sea (Tondano River). Lake Tondano has been utilized to support anthropogenic activities such as freshwater fisheries, tourism, industrial use, irrigation, and hydropower generation. Fishery using floating net cages and tourism are the dominant utilizations of Lake Tondano developed by the local communities (Nontji 2016).

The number of floating net cages in Lake Tondano was 3500 units which needed approximately 200-300 tons of feed annually. These fishery activities have increased organic waste, sedimentation and eutrophication. The domination of the 3 genera of bacteria in the bottom lake sediment namely Salmonella, Escherichia and Enterobacter will increase the environmental risk (Sumampouw and Tumbel 2013). The fishery releases an amount of nutrient rich pollutants (feces, feed waste and metabolic products). The wastes will change the water quality through the changes in the community structure of macrobenthos, the blooming of phytoplankton and the fluctuation of physical parameter values (Nabirye et al. 2016). 
Sedimentation is a threat for the Lake Tondano triggered by an increase of the erosion ratio as an effect of forest conversion. The erosion of the Tondano upstream reaches 28.86-63.00 ton/ha annually (UNSRAT 2000 in Nontji, 2016). JICA (2006) stated that $9 \%-45 \%$ of the catchment area had exceeded the normal erosion ratio. It has affected 1200 ha of the lake for 20 years period which threatens the lake sustainability (Nontji 2016). Turangan et al. (2014) describe another threat for Lake Tondano from the invasion of water hyacinth (Eichhornia crassipes) as an impact of nutrient increase.

The objectives of this research were to analyze the Lake Tondano water quality including pollution and eutrophication. Holistic analyses covering all environmental components (abiotic, biotic and socioculture) were done. The research outputs were the pollution and trophic level which can be used as the basis for the efforts to conserve the environment. This research also reviewed assessing the results of the previous research through a holistic study method.

\section{MATERIALS AND METHODS}

\section{Study area}

This research was conducted in Lake Tondano and Tondano River as a single outlet in North Sulawesi Province, Indonesia. Sampling and bioindicators analyses (plankton and benthos) were conducted in 2016.

\section{Procedures}

Materials

Material of research were documents from the previous abiotic monitoring, chemical materials for preservation of bioindicators, identification guidelines of plankton and benthos, a regulation about class of water (Government Regulation No 82 the year of 2001).

\section{Data collection}

Samples of water were collected from the sampling station located in a lake outlet, inlet I (Kakas), inlet II (Paso), inlet III (middle area of lake), inlet IV (Remboken), area V (superficial middle area), inlet VI (Peloloan), inlet VII (Tooliangki), inlet VIII (Eris), inlet IX (northern of lake), a water area near the settlement of Eris and the Tondano River. Secondary data were collected from documents of physicochemical parameters monitoring in Lake Tondano which was conducted in 2015. The data covered stations inside the lake area (Kakas, Paso, middle of lake, and Remboken, superficial area, Paleloan, and Tooliangki), settlements (Eris) and an outlet. Samples of water were collected compositely based on the depth using a water sampler for vertical point referring to the SNI 6989.57.2008 chapter 57.

\section{Data analyses}

Plankton observation was done using the Sedgwick Rafter Cell and also the Identification Guidelines. Index of Diversity was calculated with the Shannon-Weiner formula (Odum and Barrett 2009) :

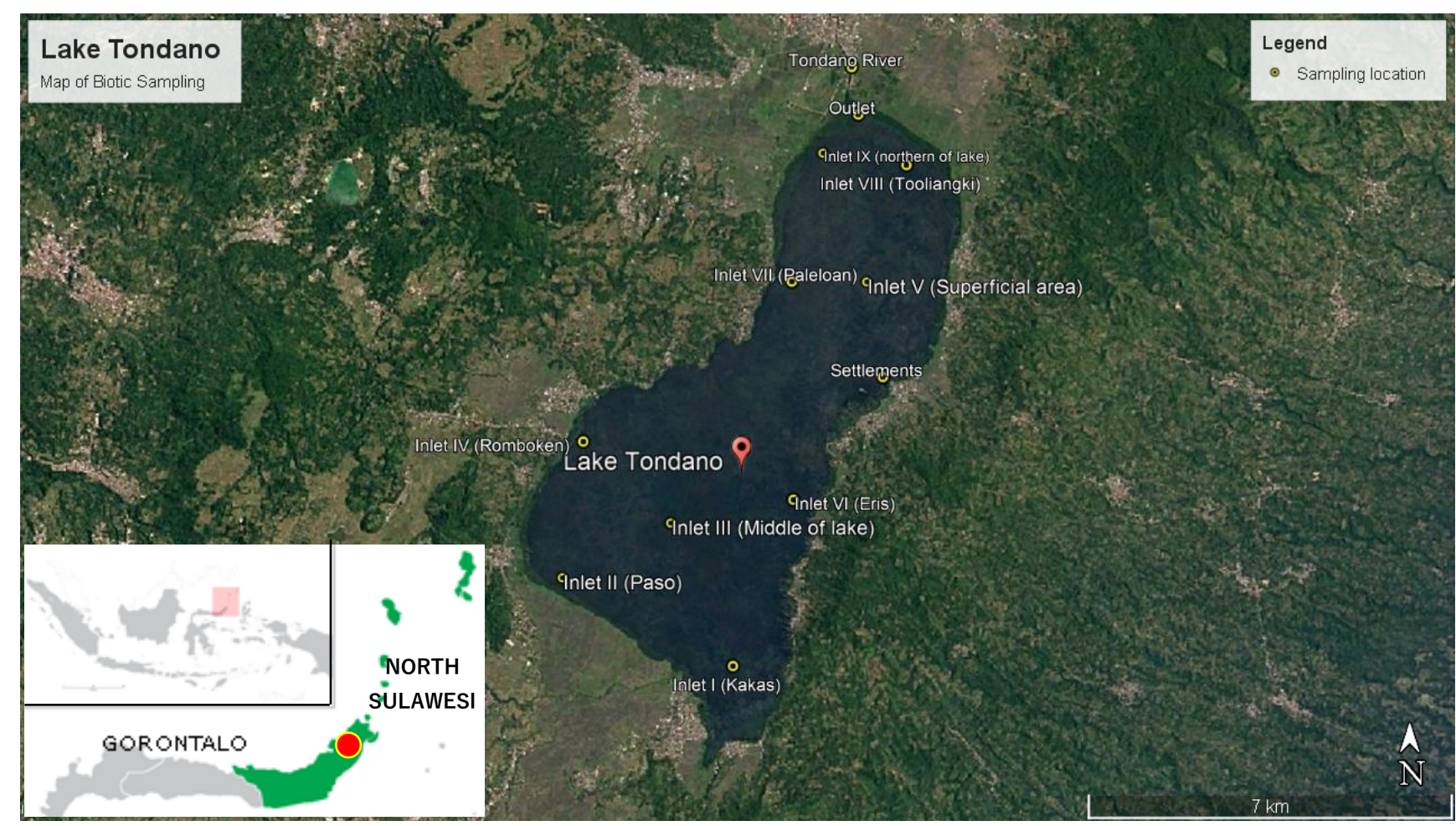

Figure 1. Map of Lake Tondano (๑), North Sulawesi, Indonesia and the sampling stations 


$$
H^{\prime}=-\sum \frac{n i}{N} \ln \frac{n i}{N}
$$

Where:

$\mathrm{H}^{\prime}$ is the diversity index of Shannon-Weiner ni is the number of a given species (i).

$\mathrm{N}$ is total of individuals observed

The diversity index was used in determining the pollution level of water based on the criteria of Wilhm (1975) (Table 1).

The level of pollution in Lake Tondano was also assessed by the value of physicochemical parameters. The physicochemical parameters were temperature, $\mathrm{pH}$, dissolved oxygen (DO), total suspended solid (TSS), level of turbidity, total-N, total-P and chlorophyl- $\alpha$ (Table 2). The physicochemical parameters of water were then compared with the standard stipulated in the Government Regulation No 82 the year of 2001 .

The determination of trophic level used the Carlson formula which uses a value of total-P and the chlorophyll- $\alpha$ (Carlson 1977).

$$
\begin{aligned}
& \text { TSI }(\text { Total P })=14.42 \times \ln (\mathrm{TP})+4.15 \\
& \text { TSI }(\text { CHL }))=9.81 \times \ln (\mathrm{Chl} \mathrm{A})+30.6
\end{aligned}
$$

Where:

TSI (Total-P) was the trophic level based on the value of total phosphates

TSI (CHL) was the trophic level based on the value of chlorophyll- $\alpha$

TP was the value of total phosphates $(\mu \mathrm{g} / \mathrm{L})$

$\mathrm{Chl}$ A was the value of chlorophyll- $\alpha(\mu \mathrm{g} / \mathrm{L})$

Because the data of Secchi Disk brightness were not available, the calculation based on brightness value was not used. The trophic level was determined by averaging Total $P$ and chlorophyll- $\alpha$. The categories of trophic level are shown in Table 3

\section{RESULTS AND DISCUSSION}

\section{The bioindicators and the diversity index}

The bioindicators identified from water samples were presented in Table 4. The phytoplankton was dominated by Navicula and Nitzschia while the zooplankton group was dominated by Asplachna and Nauplius. The number of species was evenly distributed in the group of benthos. The pollution level could be analyzed based on a diversity level. The diversity index of Shannon-Weiner in each station and pollution level was shown in Table 5 .

Individuals count on each group of aquatic organism (phytoplankton, zooplankton, and benthos) from all stations in Lake Tondano were shown in Figure 1.

The results of analyses could determine both the diversity level in each group of aquatic organism and the pollution level. Higher diversity of water organism indicates a good availability and sustainability of resource to support lives. Pollution can reduce the natural function of water to support aquatic lives because only certain species can survive in polluted water. The value of diversity index was in the range of 1.7-2.1 indicating a moderate diversity. The evenness index was in the range of 0.75-0.85 indicates that most species in the ecosystem had relatively the same numbers of individuals. Both indexes indicated a relatively balanced environment which can support the lives of aquatic organisms.

Table 1. Classification of pollution level based on the value of diversity index

\begin{tabular}{ll}
\hline Range of ID & Class of water pollution \\
\hline $0<\mathrm{H}^{\prime}<1$ & Heavily polluted \\
$1<\mathrm{H}^{\prime}<2$ & Moderately polluted \\
$2<\mathrm{H}^{\prime}<3$ & Lowly polluted \\
$3<\mathrm{H}^{\prime}<4$ & Slightly polluted \\
\hline
\end{tabular}

Table 2. Methods of analyses of physicochemical parameters in the laboratory

\begin{tabular}{lll}
\hline Parameters & Units & Analytics method \\
\hline Temperatur & ${ }^{\circ} \mathrm{C}$ & SNI 69-6989.23-2005 \\
TSS & $\mathrm{mg} / \mathrm{L}$ & SNI 06-6989.3-2004 \\
$\mathrm{pH}$ & - & SNI 06-6989.11-2004 \\
Dissolved oxygen & $\mathrm{mg} / \mathrm{L}$ & SNI 06-6989.14-2004 \\
Total-P & $\mathrm{mg} / \mathrm{L}$ & APHA M 4500-P.A \\
Turbidity & NTU & Turbidimeter \\
Chlorophyll- $\alpha$ & $\mu \mathrm{g} / \mathrm{L}$ & Spectrophotometer (Aminot and \\
& & Rey, 2002) \\
\hline
\end{tabular}

Table 3. Categories of trophic level based on average of TSI (Carlson and Simpson 1996)

\begin{tabular}{ll}
\hline Average of Trophic State Index (TSI) & Trophic level \\
\hline TSI $<30$ & Oligotrophy \\
$30 \leq$ TSI $<50$ & Mesotrophy \\
$\leq$ TSI $<70$ & Eutrophy \\
TSI $>70$ & Hypertrophy \\
\hline
\end{tabular}

Tabel 4. Plankton and benthos found in Lake Tondano Lake Tondano, North Sulawesi, Indonesia

\begin{tabular}{lll}
\hline Species name & & \\
\hline Anabaena $\mathrm{sp}$. & Tabellaria $\mathrm{sp}$. & Atopsyche $\mathrm{sp}$. \\
Ceratium $\mathrm{sp}$. & Asplanchna $\mathrm{sp}$. & Bankivia fasciata \\
Closterium $\mathrm{sp}$. & Astramoeba $\mathrm{sp}$. & Eulalia sp. \\
Cocconeis $\mathrm{sp}$. & Cyclops $\mathrm{sp}$. & Goniobasis $\mathrm{sp}$. \\
Denticula $\mathrm{sp}$. & Daphnia $\mathrm{sp}$. & Halesus \\
Euglena $\mathrm{sp}$. & Diaptomus $\mathrm{sp}$. & Hydropsyche \\
Fragilaria $\mathrm{sp}$. & Difflugia $\mathrm{sp}$. & Leptohypes $\mathrm{sp}$. \\
Gyrosigma $\mathrm{sp}$. & Eubranchipus sp. & Natica stellata \\
Navicula $\mathrm{sp}$. & Lecane $\mathrm{sp}$. & Rhinoclavis asper \\
Nitzschia $\mathrm{sp}$. & Nauplius $\mathrm{sp}$. & Tectarius coronatus \\
Surirella $\mathrm{sp}$. & Notholca $\mathrm{sp}$. & Viviparus \\
\hline
\end{tabular}



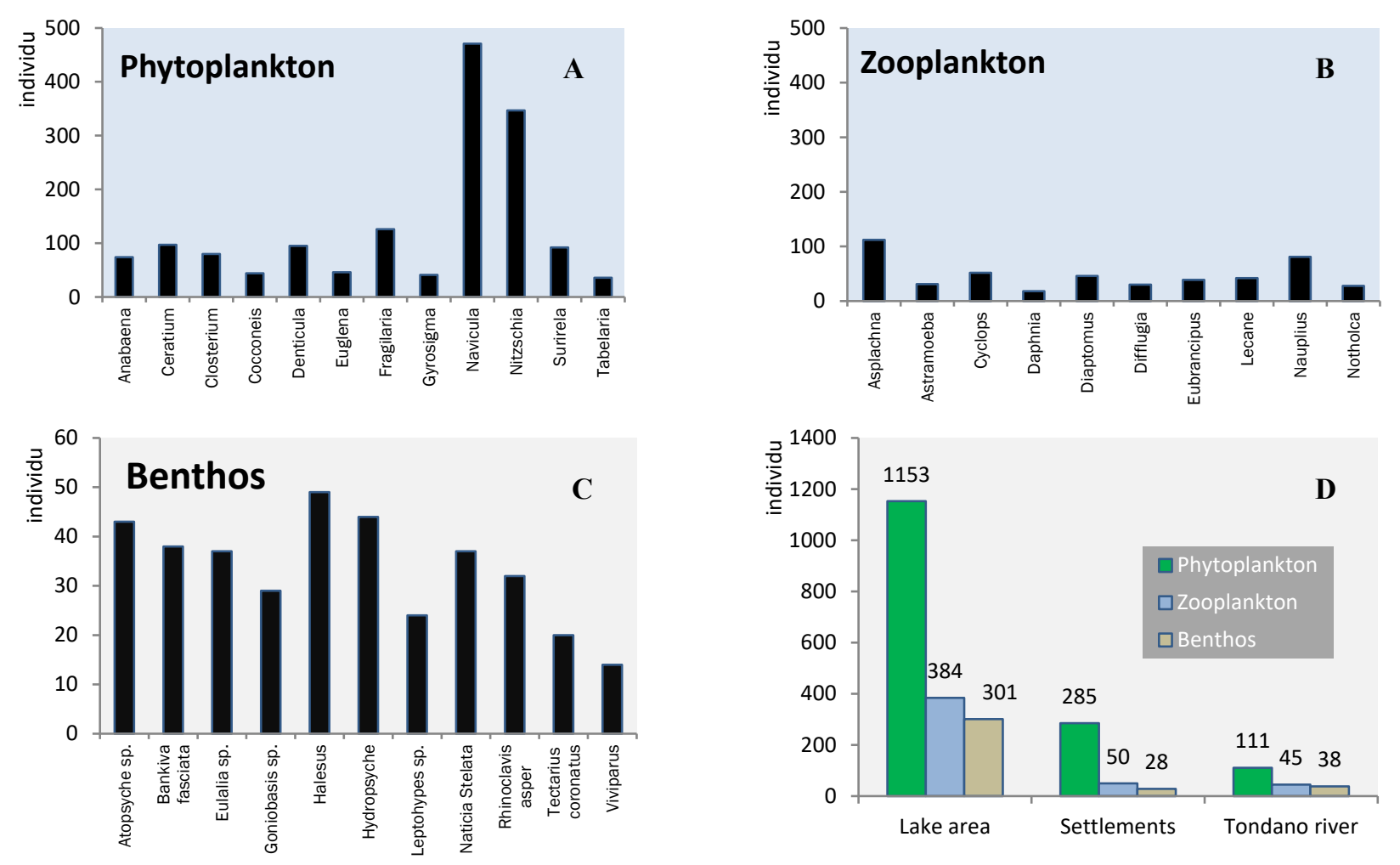

Figure 2. The number of individuals (following a clockwise) in the group of phytoplankton (A), zooplankton (B) and benthos (C); a composition on the group of organism in a sample station (D) in Lake Tondano, North Sulawesi, Indonesia

Tabel 5. Results of the analyses of diversity index (H') and the classification of pollution level in Lake Tondano, North Sulawesi, Indonesia

\begin{tabular}{|c|c|c|c|c|c|c|c|c|c|}
\hline \multirow{2}{*}{ Stations } & \multicolumn{3}{|c|}{ Phytoplankton } & \multicolumn{3}{|c|}{ Zooplankton } & \multicolumn{3}{|c|}{ Benthos } \\
\hline & $\mathrm{H}^{\prime 1}$ & $\mathbf{E}^{2}$ & Pollution level & $\mathbf{H}^{\prime}$ & $\mathbf{E}$ & Pollution level & $\mathbf{H}^{\prime}$ & $\mathbf{E}$ & Pollution level \\
\hline Outlet & 1.885 & 0.758 & Moderate & 1.804 & 0.783 & Moderate & 1.877 & 0.755 & Moderate \\
\hline Inlet I & 1.685 & 0.678 & Moderate & 1.670 & 0.725 & Moderate & 2.232 & 0.898 & Low \\
\hline Inlet II & 2.215 & 0.891 & Low & 1.454 & 0.631 & Moderate & 2.194 & 0.883 & Low \\
\hline Inlet III & 1.886 & 0.759 & Moderate & 1.877 & 0.815 & Moderate & 2.166 & 0.872 & Low \\
\hline Inlet IV & 1.644 & 0.662 & Moderate & 1.404 & 0.610 & Moderate & 2.138 & 0.860 & Low \\
\hline Inlet V & 1.890 & 0.761 & Moderate & 1.920 & 0.834 & Moderate & 2.112 & 0.850 & Low \\
\hline Inlet VI & 1.810 & 0.728 & Moderate & 1.779 & 0.773 & Moderate & 2.066 & 0.832 & Low \\
\hline Inlet VII & 1.733 & 0.698 & Moderate & 1.493 & 0.649 & Moderate & 2.084 & 0.839 & Low \\
\hline Inlet VIII & 1.905 & 0.767 & Moderate & 1.841 & 0.800 & Moderate & 1.861 & 0.749 & Moderate \\
\hline Inlet IX & 2.238 & 0.901 & Low & 1.571 & 0.682 & Moderate & 2.195 & 0.883 & Low \\
\hline Eris settlement & 1.810 & 0.728 & Moderate & 1.592 & 0.691 & Moderate & 1.918 & 0.772 & Moderate \\
\hline Tondano river & 2.154 & 0.867 & Low & 2.141 & 0.930 & Low & 2.196 & 0.884 & Low \\
\hline Average & 1.905 & 0.766 & Moderate & 1.712 & 0.744 & Moderate & 2.087 & 0.840 & Low \\
\hline
\end{tabular}

Note: ${ }^{1} \mathrm{H}$ ': diversity index of Shannon Weiner, ${ }^{2} \mathrm{E}$ : Eveness

\section{Analyses of pollution level based on physicochemical parameters}

Pollution level in physicochemical (abiotic) components was determined using the standard stated in the Government Regulation Number 82, the year of 2001. Low class indicates a low level of pollution and several types of uses can be done with the water, meaning a good quality of water. The data of physicochemical parameters were monitored by the limnology team of LIPI in 2015
(Sudarso et al. 2015). The data were collected from relatively similar stations with the biotic sampling. Monitoring has been conducted to measure temperatures, $\mathrm{pH}$, dissolved oxygen, total suspended solids, level of turbidity, total-N, total-P and the chlorophyll- $\alpha$. The appropriateness of use was evaluated based on all physicochemical variables except for turbidity and chlorophyll- $\alpha$ because the regulation doesn't have the standard for both parameters. 
Table 6. Physicochemical parameters and comparison with quality standard for the water utilization classification in Lake Tondano, North Sulawesi, Indonesia

\begin{tabular}{llllllllll}
\hline \multirow{2}{*}{ Station } & & \multicolumn{4}{c}{ Physicochemical parameters } & \multicolumn{3}{c}{ Class of } \\
& Temp. & pH & DO & TSS & Turbidity & Total-N & Total-P & Chl- $\alpha$ & water * \\
\hline Kakas & 25.575 & 7.15 & 6.325 & 16.815 & 38.5 & 1.405 & 0.07 & 2.86 & Class II \\
Paso & 25.85 & 8.05 & 5.17 & 16.415 & 13.55 & 1.285 & 0.155 & 9.965 & Class II \\
Middle of lake & 25.785 & 7.75 & 4.815 & 4.335 & 171.815 & 1.705 & 0.13 & 3.27 & Class II \\
Remboken & 26.6 & 7.6 & 5.505 & 7.42 & 229.59 & 1.07 & 0.16 & 4.085 & Class II \\
Eris & 25.485 & 7.65 & 3.53 & 12.735 & 69.115 & 0.955 & 0.14 & 6.04 & $<$ Class II \\
Superficial area & 26.145 & 7.4 & 4.36 & 16.75 & 12.365 & 1.605 & 0.145 & 7.36 & Class II \\
Paleloan & 26.255 & 7.75 & 4.925 & 10.915 & 18.39 & 0.675 & 0.09 & 6.64 & Class II \\
Tooliangki & 26.195 & 7.35 & 5.23 & 11.235 & 15.04 & 0.815 & 0.09 & 6.07 & Class II \\
Outlet & 26.15 & 7.6 & 5.875 & 6.465 & 25.765 & 0.575 & 0.095 & 5.315 & Class II \\
\hline
\end{tabular}

Note: Sudarso et al. (2015); determination of the class of utilization was based on the standard quality of Government Regulation No. 82 the year of 2001

Table 7. The TSI value at Lake Tondano, North Sulawesi, Indonesia

\begin{tabular}{lcccc}
\hline Stations & TSI (TP) & TSI (Chl- $\boldsymbol{\alpha})$ & Average & Category \\
\hline Kakas & 65.41 & 40.91 & 53.16 & Eutrophy \\
Paso & 76.88 & 53.15 & 65.02 & Eutrophy \\
Middle of lake & 74.34 & 42.22 & 58.28 & Eutrophy \\
Remboken & 77.33 & 44.41 & 60.87 & Eutrophy \\
Eris & 75.41 & 48.24 & 61.83 & Eutrophy \\
Superficial Area & 75.91 & 50.18 & 63.05 & Eutrophy \\
Paleloan & 69.04 & 49.17 & 59.10 & Eutrophy \\
Tooliangki & 69.04 & 48.29 & 58.66 & Eutrophy \\
Outlet & 69.82 & 46.99 & 58.40 & Eutrophy
\end{tabular}

Note: ${ }^{1}$ Stations is the abiotic sampling stations; ${ }^{2}$ trophic level based on the value of total-P; ${ }^{3}$ trophic level based on the value of chlorophyll- $\alpha$.

\section{Analyses of Trophic State Index (TSI)}

Trophic level analyses were done using the Carlson formula to calculate the Trophic State Index (TSI) which utilizes the value of chlorophyll- $\alpha$, total-P and the brightness of Secchi disk. Only the data of total-P and chlorophyll- $\alpha$ were available in the documents of the physicochemical monitoring from LIPI (Sudarso et al 2015). Nevertheless, both data were considered sufficient to represent the trophic level because of the availability of chlorophyll- $\alpha$ value. Chlorophyll- $\alpha$ is considered a strong variable to describe the organic pollution, phytoplankton blooming and also trophic condition in specific wetlands. Each of the three elements (Total-P, chlorophyll- $\alpha$, and brightness) has a role as an independent estimator, not a covariate (Carlson 1983).

\section{Discussion}

Lake Tondano is an estuary of 12 rivers and 25 tributaries. The BPPT (2008) observed that 3 rivers were the main contributors to organic pollution at Lake Tondano namely: Ranoweleng, Panasen, and Leleko. Their contribution results in the decline of water quality. Lake outlet located in the north passes Tondano River and ends in the Manado Bay. Today, Tondano River used as the source of water supply for local government drinking water company (PDAM).
Mende et al. (2015) detected the contribution of domestic waste from 4 villages adjacent to the lake area: Leleko, Paslaten, Talikuran and Timur, all of which are located in Remboken Sub-district, Minahasa, North Sulawesi. The villagers usually dispose of domestic waste to the water body, and at the same period, their settlement was affected by the change of lake elevation. In this condition, the domestic waste will have a greater potency to float into the intertidal zone of lake.

The depth of Lake Tondano influences water circulation which in turn affects water quality. Measurement by Wetlands International-Indonesia Programme (WIIP 2010) recorded the most shallow area $(0-14 \mathrm{~m})$ at the northern part of lake which was the general depth of the lake area $(72.50 \%)$. The deepest area $(22-34 \mathrm{~m})$ was located in the eastern part of lake, which was a narrow area $(0.003 \%)$, close to a crowded settlement on the Eris District. The lake outlet was a shallow area which makes an interference in the water circulation. The pollutants have a tendency to settle in deep water in the northern and eastern parts of the lake. This condition was aggravated by the crowded settlements which potentially dispose of domestic waste constantly to the water.

In 2006, Lake Tondano had approximately 3500 units of floating fish cages. The latest inventory in 2014 showed an increase of the number, reaching 10.874 units especially at Eris and Toulimempet. The fisheries produced $30 \%$ of feed wastes and $25-30 \%$ feces as the entropy. Most of the floating fish cages were not equipped with an adequate waste filter so that wastes sank easily and accumulated as pollutant, which potentially causes eutrophication (Kusen et al. 2014).

The bioindicator indicates environmental condition and their changes periodically through a biological process. A community's attributes can describe the environmental stability from the diversity value related to the balance of population (Holt and Miller 2011). Planktons are ideal indicators of the change of water system because of their sensitivity to the fluctuation of environmental condition (Hemraj et al. 2017) including changes in physicochemical parameters and anthropogenic pollution especially at catchment area (Dembowska et al. 2015). 
Phytoplanktons are good bioindicators. The community of phytoplankton can give accurate information about water quality, better than the results of nutrient analyses (Medupin 2011) because they show quick response to the degradation of environmental quality (Jindal et al. 2014). Phytoplankton plays an important role in energy transfer at the lake ecosystem (Darchambeau et al. 2014). Zooplankton responds to a wide range variation of environmental changes including the addition of nutrients, acidification, and input of sediments. Zooplankton also has a good role as the bioindicators of eutrophication. Zooplankton is the first consumer in the food chain which has a significant value for the fishery activities (Ahmad et al. 2011). In this research, the amount of zooplankton is lower than that of phytoplankton.

The presence of Navicula as dominant phytoplankton in Lake Tondano (Figure 2) indicated low-moderate pollution. The condition was confirmed by the presence of Nitzschia as the second dominant genus observed. Nitzschia is phytoplankton with high tolerance to pollution. The presence of Nitzschia in large number indicates the potential pollution in the sampling location. This was the case in Tondano River where Nitzschia group was found larger than Navicula.

The pollution level based on the diversity of the three groups of organisms was low-moderate level. The benthos diversity indicated a low level of pollution in all areas except in outlet. The outlet passed a settlements area which has a potential contribution of domestic wastes. The study resulted in consistent conclusion with similar assessment using the biodiversity and similarity level.

A different conclusion was observed in approaches of pollution assessment between benthos and plankton. The plankton diversity indicated moderate pollution while the benthos diversity indicated low pollution. This condition had been predicted as the effects of depth and character of monitoring stations. Most of the pollutant sediments accumulated in the specific location. The number of benthos was even because of their tolerance for a change in the water quality. Some of macrobenthos have a role as the filter feeder in the bottom of waterbody, receiving all materials and waste of feed. The incidence of various level of pollution in water gives two main impacts. First, poorly tolerant organisms will move to another location with a tolerable level of pollution or even became extinct. Second, highly tolerant organisms will survive, breed and dominate the polluted environment until the pollution level exceeds their limit of tolerance.

This research recorded an macrophytes (Eichhornia crassipes) blooming in all stations except in the middle of lake. The algal blooming indicated imbalance of nutrients in the water as an effect of anthropogenic activities inside the lake (freshwater fisheries in Kakas, Eris, Remboken and tourism in Remboken) as well as activities around the lake (domestic activities in Paso, Eris and Paleloan; an agriculture in Tooliangki; and a riverbank erosion in Kakas and Tooliangki). Anthropogenic activities contribute to the abundance of nutrients for the group of producers in water.

The result of physicochemical analyses from composite samplings at the water surface and bottom of lake are presented in Table 7. Today, the water of Lake Tondano was utilized as water supply for local drinking water company (PDAM) so the quality of it must be high. According to the Government Regulation No 82, the year of 2002, the DO value exceeded the pollution threshold of first-class water $(6 \mathrm{mg} / \mathrm{L})$. The water of Lake Tondano was categorized as $2^{\text {nd }}$ class water, which is suitable for use in recreation, fisheries, animal husbandry, irrigation and other utilization with similar standard of water quality. The water in most of the stations was qualified for the $2^{\text {nd }}$ class water except in Eris area (station V). The Eris station had a DO value lower than $4 \mathrm{ppm}$. A review of water quality standard based on the Decree of North Sulawesi Governor number 99 the year of 2003 showed the same results. The regulation declared the suitable utilization of Lake Tondano water was only for the $2^{\text {nd }}$ class.

Having a high value of DO does not always means that the water is suitable for a specific function. Research in the Gajah Mungkur Reservoir showed stability in DO values in a depressed condition of aquatic environment with high value of $\mathrm{BOD}$ and $\mathrm{COD}$ caused by eutrophication. This research identified similar sources of pollution namely the domestic and fishery activities. Domestic waste varies with seasonal changes especially intensity of rain and run off (Wiryanto 2016).

The trophic state is defined as the total weight of biological materials (biomass) in a specific location and period (Negro and Hoyos 2005). Qin et al. (2013) reveal that lakes eutrophication correlates with an increase of the elementary biological substances (including nitrogen and phosphorus) which are needed by plants or groups of aquatic producers so the increase of nutrients will increase the productivity of aquatic ecosystem. Akdeniz et al. (2011) state that blooming of Protista organisms contributed by anthropogenic and natural activities will trigger eutrophication. The trophic state can be understood as a biological response to overcome various factors like the nutrient increase although the effects are probably caused by natural conditions. In the TSI Carlson formula, phytoplankton is represented by chlorophyll-although in trophic water the chlorophyll- $\alpha$ may come from another type of producers.

The result of Carlson calculation categorized the trophic level of lake Tondano's water as eutrophy category based on the value of TSI (TP) and TSI (Chl- $\alpha)$. The eutrophy category indicates a status of water with a high content of nutrients. This status also indicates excess contamination of nutrients which affect the level of $\mathrm{N}$ and $\mathrm{P}$ in water. A tangible indicator was waterhyacinth blooming in entirely lake area except in the middle of lake.

The blooming and domination of waterhyacinth were observed significantly in Lake Tondano according to the research by Turangan et al. (2014) using a satellite image and ArcGIS analyses. The plants grew and spread with high intensity. The area of water hyacinth in Lake Tondano increased from 130.77 ha $(2.82 \%)$ in 2006 to 292.66 ha $(6.32 \%)$ five years later. The hyacinth area growth ratio was 32.38 ha annually. The rapidly growing hyacinth is predicted to become a destructive weed in aquatic 
ecosystem, major cause of the degradation of water quality, a trigger of eutrophication and a silting factor.

Chlorophyll- $\alpha$ has a important role in the water trophic calculation than the 3 other factors (Rakocevic and Hollert 2005). Analyses of other nutrients (like N) becomes a complementary option as comparison to asses a suitability of trophic level in waterbody. Trophic state index (TSI) of Chlorophyll- $\alpha$ indicated a moderate level of trophic in Lake Tondano which had a tendency to be closer to the hypertrophic condition $(20<\mathrm{TSI}<50)$. A hypertrophy refers to a worse condition of water trophic level indicated by a blue-green algae blooms, an appearance of algal waste and macrophyte problems.

Domination of diatoms phytoplankton (Navicula and Nitzschia) was an indicator of a high trophic condition in Lake Tondano in addition to the blooming of Eichhornia crassipes. The diatoms require a high nutrient water than the availability of abundant light. It makes diatoms difficult to survive in oligotrophic water (Winder et al. 2009). Monitoring on biotic component (Figure 2) found a large amount of plankton and benthos inside the lake area as the cause of a lentic character, an abundant supply of nutrients and a more suitable pollutant contents than a river water.

Plankton analyses in the settlement area of Lake Tondano resulted in inequality between an amount of phytoplankton and zooplankton. This condition was a strong indication of nutrient abundance in the settlement area as the effects of various activities which have contribution on the trophic level. A primary observation found that settlement area like Eris was not only utilized for domestic interests but also developed as a central of freshwater fisheries using a float net cages. Therefore, this area produced domestic and fishery wastes which had equal contribution on the nutrients added.

Review of zooplankton showed a relatively equal number of the species. Asplachna appeared the most abundant genus in Kokas, Paleloan, an outlet area and dense settlements. Asplachna is known as an indicator of organic pollution (Ahmad 2011) which may cause eutrophication in lakes. The location with a large amount of Asplachna had various activities (a river inlet, agriculture, a freshwater fishery, and settlements) which potentially contributed large nutrients pollutants.

The abundance of zooplankton generally is not affected significantly by a level of trophic. Zooplankton has a strong correlation with a condition of extreme pollution which impacts physicochemical variables like BOD, DO and $\mathrm{pH}$ (Illyova and Pastuchova 2012) and other temporal fluctuation. The condition had been observed in lake Tondano as indicated by an increase of zooplankton following the rise of eutrophication. This condition was the effects of available nutrients and a suitable condition of physicochemical variables.

An alternative method for determining trophic level of lake is utilizing the total-N value. This approach was introduced by Kratzer and Brezonik (1981), formulated below (Gupta 2014): TSI $(\mathrm{TN})=54.54+14.43 \ln (\mathrm{TN})$. Where, TSI (TN) is total state index based on a calculation of total-N, TN is total $\mathrm{N}(\mathrm{mg} / \mathrm{L})$. Kratzer and Brezonik classify the TSI (TN) value into 4 classes with TSI
$(\mathrm{TN})<20$ being ultraoligotrophic, $30<\mathrm{TSI} \quad(\mathrm{TN})<40$ oligotrophic, $53<\mathrm{TSI}<60$ eutrophic and TSI (TN) $>70$ hypertrophic (Harper 1992). Calculation of TSI (TN) in Lake Tondano resulted in a range of value of $46.55<$ TSI $(\mathrm{TN})<62.24$ categorized as eutrophic according to the classification of Kratzer-Brezonik. The result of TSI (TN) analyses was similar to the trophic level analyses with the Carlson method.

Pollution and trophic status in Lake Tondano showed a dangerous trend on the sustainability of water. Pollution mostly resulted from nutrient overload which increased water trophic level. Anthropogenic utilization like freshwater fisheries also threatened the lake with eutrophication. The eutrophication will disturb the stability of the zooplankton community which is the key factor in the fishery productivity in the future. In Lake Tondano, pollution and eutrophication were the results of various activities in and around the lake. Eutrophication increases naturally in a long period with the anthropogenic activities as the boosting factor of this process.

This research found conformity between the analyses of bioindicators and physicochemical parameters with regard to pollution and trophic level. Lake Tondano showed lowmoderate pollution with a suitable utilization for the $2^{\text {nd }}$ class of water (except for Eris station). Tondano River had worse pollution indicated by the presence of Nitzschia as the dominant phytoplankton. The analyses of trophic level using the Carlson method, the Kratzer Brezonik method and the study on bioindicators showed results indicating moderate eutrophic status which could become hypertrophic if the anthropogenic activities are uncontrolled. A key bioindicator of low pollution in lake Tondano was Navicula while Nitzscia was an indicator of low pollution in Tondano River and Navicula, Nitzschia (phytoplankton), Asplachna (zooplankton) and Eichhornia crassipes (macrophytes) were indicator of eutrophication.

The prevention of increase of trophic level in The LakeTondano can be done with revegetation on the green belt area. This effort will reduce soil erosion and run off ratio, especially from agriculture, settlements and other land use activities. Pollution can be reduced by strict regulation and construction of a communal waste water installation. An important aspect is empowerment of community role in lake management utilizing the local wisdom. These efforts not only involve local communities but also global communities receiving the economic profit from Lake Tondano.

The floating fish cages should get large attention because they give significant contribution to the pollution and trophic level. The growth of floating fish cages should be regulated and restricted to give a recovery time on Lake Tondano. The efforts can be started with reducing the amount of waste by modification of feed type and dosage, improvement on filtering ability, adjustment of the cleaning period and also selection of the fish species. Junaidi et al. (2014) observed an increasing amount of water pollution as impacts of the fishery waste using mass mortality of fish. 


\section{REFERENCES}

Ahmad U, Parveen S, Khan AA, Kabir HA, Mola HRA, Ganal AH. 2011 Zooplankton Population in Relation to Physico-Chemical Factors of A Sewage Fed Pond of Aligarh (UP), India. Biology and Medicine 3 (2) Special Issue: 336-341

Akdeniz S, Karaer F, Katip A, Aksoy E. 2011. A GIS based Method for Shallow Lake Eutrophication Assesment. J Biol Environ Sci 5 (15): 195-202

American Public Health Association. 1992. APHA Method 4500-P : Standard method for the examination of water and wastewater (A Phosporus)

Aminot, A, Rey, F. 2002. Standard procedure for the determination of chlorophyll a by spectroscopics method. International Council for The Exploration of The Sea

Avans AEV, Hanjra MA, Jiang Y, Qadir M, Dreschel P. 2012. Water Quality: Assesment of the Current Situation in Asia. Water Res Dev 28 (2): 195-216.

Badan Standardisasi Nasional. 2004. SNI 06-6989.3-2004 : Cara uji padatan tersuspensi total (Total Suspended Solid, TSS) secara Gravimetri

Badan Standardisasi Nasional. 2004. SNI 06-6989.11-2004 : Air dan air limbah-Bagian 11 : Cara uji derajat keasaman $(\mathrm{pH})$ dengan menggunakan alat $\mathrm{pH}$ meter

Badan Standardisasi Nasional. 2004. SNI 06-6989.14-2004 : Air dan air limbah-Bagian 14 : Cara uji oksigen terlarut secara yodometri

Badan Standardisasi Nasional. 2005. SNI 06-6989.23-2005 : Air dan limbah - Bagian 23 : Cara uji suhu dengan termometer

Badan Standardisasi Nasional. 2008. SNI 06-6989.23-2008 : Air dan limbah - Bagian 57 : Metoda pengambilan contoh air permukaan

Qin BQ, Gao G, Zhu GW, Zhang ZL, Song ZY, Tang XM, Xu H, Deng JM. 2013. Lake eutrophication and ecosystem response. Chinese Sci Bull 58 (9): 961-970.

Carlson RE, Simpson J. 1996. A Coordinators Guide to Volunteer Lake Monitoring Methods. North American Lake Management Society, Madison, Wisconsin.

Carlson RE. 1977. A Trophic State Index for Lakes. Limnol Oceanogr 22 (2): 361-369

Carlson RE. 1983. Discussion on “Using Differences Among Carlson's Trophic State Index Values in Regional Water Quality Assesment" by Richard Osgood. Water Resour Bull 19: 307-309.

Chalar G, Arocena R, Pacheco JP, Fabian D. 2011. Trophic assessment of streams in Uruguay: A Trophic State Index for Benthic Invertebrates (TSI-BI). Ecol Indicat 11: 362-369.

Darchambeau F, Sarmento H, Descy JP. 2014. Primary production in a tropical large lake: The role of phytoplankton composition. Sci Total Environ 473-474: 178-188.

Dembowska EA, Napiorkowski P, Mieszczankin T, Josefowitz S. 2015 Planktonic indices in the evaluation of the ecological status and the trophic state of the longest lake in Poland. Ecol Indicat 56: 15-22.

Dodson SI, Arnott SE, Cottingham KL (2000) The relationship in lake communities between primary productivity and species richness. Ecology 81(10): 2662-2679.

Effendi H. 2016. River water quality preliminary rapid assessment using pollution index. Procedia Environ Sci 33: 562-567.

Government of Republic Indonesia Regulation Number 82 the Year of 2001 about "Water Quality Management and Pollution Control"

Gupta M. 2014. A New Trophic State Index for Lagoon. J Ecosyst 2014 article 152473. DOI: 10.1155/2014/152473

Harper D. 1992. Eutrophication of Freshwater: Principles, Problems and Restoration. Springer, Dordrecht.

Hemraj DA, Hossain MdA, Ye Q, Qin JQ, Leterme SC. 2017. Plankton Bioindicators of Environmental Conditions in Coastal Lagoons. Estuarine Coastal and Shelf Science 184 (2017): 102-114. DOI: 10.1016/j.ecss.2016.10.045

Holt EA, Miller SW. 2011. Bioindicators: Using Organisms to Measure Environmental Impacts. Nature Educat Knowl 2 (2): 8.
Illyova M, Pastyuchova Z. 2012. The zooplankton communities of small water reservoirs with different trophic conditions in two catchments in Western Slovakia. Limnologica 42: 271-281.

Ismest'eva LR, Moore MV, Hampton SE, Ferwerda CJ, Gray DK, Woo KH, Pislegina HV, Kraschuk RS, Shimaraeva SV, Silow EA. 2015. Lake-wide Physical and Biological Trends Associated With Warming in Lake Baikal. Journal of Great Lakes Research 42: 6-17.

Jindal R, Thakur RK, Singh UB, AS Ahluwalia. 2014. Phytoplankton dynamics and water quality of Prashar Lake, Himachal Pradesh India. Sustain Water Quality Ecol 3-4: 101-113.

Junaidi, Syandri H, Azrita. 2014. Loading and distribution of organic materials in Maninjau Lake West Sumatra Province, Indonesia. J Aquac Res Dev 5: 278. DOI:10.4172/2155-9546.1000278.

Kusen DJ, Marsoedi, Kusuma Z, Tamod Z. 2014. Environmental friendly foods in the cultivation of floated net cages at Tondano Lake in North Sulawesi Province. Scholars Acad J Biosci 2 (12A): 877-881.

Medupin C. 2011. Phytoplankton community and their impact to the water quality: An analyses of Hollingsworth Lake, UK. J Appl Sci Environ Manag 15 (2): 347-350

Mende JCC, Kumurur VA, Moniaga LL. 2015. Kajian sistem pengelolaan air limbah pada permukiman di kawasan sekitar Danau Tondano (Studi Kasus: Kecamatan Remboken Kabupaten Minahasa. Jurnal Sabua 7 (1): 395-406. [Indonesian]

Nabirye H, Mwebaza-Ndawula L, Bugenyi FWB, Muyodi FJ. 2016. The evaluation of cage fish farming effects om water quality using selected benthic macro-invertebrate community parameters in the Napoleon Gulf, Northern Lake Victoria. Intl J Fish Aquat Stud 4 (1): 42-50.

Negro AI, Hoyos C De. 2005. Relationships Between Diatoms and The Environment in Spanish Reservoir. Limnetica 24 (1-2): 133-144

Nontji A. 2016. Danau Tondano. Pusat Penelitian Limnologi LIPI, Cibinong, Bogor.

Odum, EP, Barrett, GW. 2009. Fundamentals of Ecology, 5th ed, Cengage Learning, Melbourne

Rakocevic ND, Hollert H. 2005. Phytoplankton community and chlorophyll- $\alpha$ as trophic states indices of Lake Skadar (Montenegro, Balkan). Environ Sci Pollut Res Int 12 (3): 146-152.

Soeprobowati TR, Tandjung SD, Sutikno Hadisusanto S, Gell P, Hadiyanto, Suedy SWA. 2016. The water quality parameters controlling diatoms assemblage in Rawapening Lake, Indonesia. Biodiversitas 17 (2): 657-664.

Sudarso J, Imroatussholikhah, Muit. 2015. Komunitas makrozoobentos di dua tipe mikrohabitat Danau Tondano. Jurnal Oseanologi dan Limnologi Indonesia 1 (3): 329-340. [Indonesian]

Sumampouw HM, Tumbel FM. 2013. Identification bacterial genus from floating net sediment in Tondano Lake in Biology Learning of Biology Students in FMIPA UNIMA. Journal of Education and Practice 4 (26): 81-86.

Turangan TMB, Leksono AS, Soemarno, Arfiati D. 2014. Innovation of water hyacinth (Eichhornia crassipes) in the surface water of Tondano Lake. Intl J Curr Res 6 (3): 5470-5476.

Vollenweider RA. 1968. Scientific Fundamentals of the Eutrophication of Lakes and Flowing Waters with Particular Reference to Nitrogen and Phosphorus as Factors in Eutrofication. Organisation for Economic Co-operation and Development, Paris.

WIIP. 2010. Laporan Survey Danau Tondano. Wetlands International Indonesia Programme (WIIP), Bogor. [Indonesian].

Winder M, Reuter JE, Schladow SG. 2009. Lake Warming Favours Small Sized Planktonic Diatom Species. Proc R Soc B 276: 427-435.

Wiryanto. 2016. Spatial and temporal description of water pollution status of Gajah Mungkur Reservoir Central Java, Indonesia. Biodiversitas 17 (2): 894-899.

Xu J, Zhang M. 2012. Primary consumers as bioindicators of nitrogen pollution in lake planktonic and benthic food webs. Ecol Indicat 14: 189-196. 